\title{
LETTER
}

\section{Substitution of exudative trace element losses in burned children}

\author{
Pascal Stucki', Marie-Hélène Perez', Jacques Cotting', Alan Shenkin² and Mette M Berger ${ }^{3 *}$
}

We describe an intravenous copper-selenium-zinc substitution policy in children with major burns using adult doses adapted to total body surface area. Blood levels and clinical course confirm its safety, with a rapidly favourable clinical evolution.

Major burn injuries are associated with trace element deficiencies, which lead to impaired wound healing and infectious complications. Low plasma levels of zinc $(\mathrm{Zn})$ and copper $(\mathrm{Cu})$ are inadequately compensated for during hospitalization [1], and enteral supplements are unsuccessful in correcting the status [2]. Additionally, there are currently no clear recommendations regarding trace element requirements in children. The aim of the present study was to determine if our trace element supplementation policy for adults adapted to total body surface area would achieve normalization of plasma concentrations of trace elements in burned children.

Burned children admitted to the paediatric and adult ICU were enrolled after approval by the Institutional Ethics Committee and parental informed consent. Parkland formula was used for fluid resuscitation during the first 24 hours in addition to basal fluid requirements $\left(1,800 \mathrm{ml} / \mathrm{m}^{2}\right)$. Target nutrition from 36 to 48 hours was: 3 to 5 year olds, 70 to $90 \mathrm{kcal} / \mathrm{kg} /$ day; over 5 year olds, 50 to $70 \mathrm{kcal} / \mathrm{kg} /$ day; teenagers, $40 \mathrm{kcal} / \mathrm{kg} /$ day. A normal saline solution containing $\mathrm{Cu}$, selenium (Se), and $\mathrm{Zn}$ (Table 1) [3] was infused continuously first within 12 hours of injury and then over 8 hours per day for 7 to 15 days at a dose of $250 \mathrm{ml} / 1.70 \mathrm{~m}^{2} /$ day along with a standard parenteral multi-trace element preparation. In addition, children admitted to the paediatric ICU received vitamin C $30 \mathrm{mg} / \mathrm{kg} /$ day and vitamin $\mathrm{E}$ $1.5 \mathrm{mg} / \mathrm{kg} /$ day; teenagers managed in the adult ICU received vitamin $\mathrm{C} 10.8 \mathrm{mg} / \mathrm{kg} /$ day and vitamin $\mathrm{E}$ $8.3 \mathrm{mg} / \mathrm{kg} /$ day (Table 1). The length of mechanical ventilation, and ICU and hospital length of stay were recorded.

*Correspondence: Mette.Berger@chuv.ch

${ }^{3}$ Adult Intensive Care Medicine Service and Burn Center, CHUV BH-08.612, Rue du

Bugnon 46, CH-1011 Lausanne, Switzerland

Full list of author information is available at the end of the article
Table 1. Composition of the antioxidant micronutrient solutions used in the adult ICU

\begin{tabular}{|c|c|c|}
\hline Micronutrient & $\begin{array}{l}\text { Intravenous } \\
\text { CHUV-TE-flex } \\
(250 \mathrm{ml})\end{array}$ & $\begin{array}{l}\text { Enteral antioxidant } \\
\text { glutamine solution } \\
\left(500 \mathrm{ml} \text {; Intestamine }{ }^{\circledR}\right)\end{array}$ \\
\hline Copper (mg) & 3.75 & - \\
\hline Selenium ( $\mu \mathrm{g})$ & 375 & 300 \\
\hline Zinc (mg) & 37.5 & 30 \\
\hline Phosphate (mg) & 1,200 & - \\
\hline Vitamin E (mg) & - & 500 \\
\hline Vitamin C (mg) & - & 150 \\
\hline Beta-carotene (mg) & - & 10 \\
\hline Glutamine (g) & - & 30 \\
\hline
\end{tabular}

$T E$, trace elements: copper gluconate, sodium selenite solution, and zinc gluconate (Laboratoires Aguettant, Lyon, France), plus a multi-trace element preparation (Decan ${ }^{\oplus}$, Aguettant). Intestamin ${ }^{\oplus}$, Fresenius Kabi AG, Stans, Switzerland.

The characteristics of all those enrolled, mean daily total trace element dose, per kilogram dose, and duration of supplementation are shown in Table 2. Figure 1 shows the individual plasma values of the four patients while in the ICU. Both teenagers (patients 3 and 4) who received additional enteral trace elements had the lowest values although within normal ranges - probably reflecting higher requirements due to growth.

The present study is the first to show that large amounts of $\mathrm{Cu}, \mathrm{Se}$ and $\mathrm{Zn}$ delivered intravenously are barely sufficient to normalize plasma concentrations in burned children. The amounts delivered are much larger than the usual nutritional per kilogram basis requirements [4], but are required to substitute cutaneous losses and normalize the activity of plasma glutathione peroxidase.

Our hypothesis that children may need somewhat larger amounts of trace elements than adults is supported by our results. These data, combined with two recent paediatric studies $[1,5]$, suggest such a substitution policy is safe and should be considered in burn units.

Competing interests

The authors declare that they have no competing interests. 
Table 2. Patient characteristics and intervention details

\begin{tabular}{|c|c|c|c|c|c|c|c|c|c|c|c|c|}
\hline Patient & $\begin{array}{c}\text { Age } \\
\text { (years) }\end{array}$ & $\begin{array}{l}\text { Weight }(\mathrm{kg}) / \\
\text { height }(\mathrm{cm})\end{array}$ & $\begin{array}{c}\text { Body } \\
\text { surface } \\
\text { area }\left(m^{2}\right)\end{array}$ & PRISM & $\begin{array}{l}\text { Burned } \\
\text { surface } \\
\% \text { TBSA }\end{array}$ & $\begin{array}{c}\text { Plasma } \\
\text { albumin } \\
\text { on D1, } \\
\text { D5, D10 } \\
\text { D20 (g/l) }\end{array}$ & $\begin{array}{l}\text { Length } \\
\quad \text { of } \\
\text { mechanical } \\
\text { ventilation } \\
\text { (days) }\end{array}$ & $\begin{array}{l}\text { Length } \\
\text { of } \\
\text { ICU stay } \\
\text { (days) }\end{array}$ & $\begin{array}{c}\text { LOS } \\
\text { (days) }\end{array}$ & $\begin{array}{l}\text { Percentage } \\
\text { of adult } \\
\text { intravenous } \\
\text { dose and } \\
\text { duration }\end{array}$ & $\begin{array}{l}\text { Daily } \\
\text { dose }\end{array}$ & $\begin{array}{c}\text { Daily dose } \\
\text { per } \\
\text { kilogram }\end{array}$ \\
\hline \multirow[t]{3}{*}{1} & 8.5 & $20 / 110$ & 0.78 & 4 & Total 53\% & $21 / 29 / 26 / 32$ & 2 & 22 & 54 & $47 \%, 15$ days & Cu 2.6 mg & Cu $0.13 \mathrm{mg}$ \\
\hline & & & & & Surgical 21\% & & & & & & Se $177 \mu \mathrm{g}$ & Se $8.9 \mu \mathrm{g}$ \\
\hline & & & & & & & & & & & Zn $27 \mathrm{mg}$ & Zn $1.4 \mathrm{mg}$ \\
\hline \multirow[t]{3}{*}{2} & 3 & $13 / 98$ & 0.59 & 1 & Total 14\% & 27/31/32/- & 11 & 12 & 23 & $21 \%, 7$ days & Cu 0.9 mg & Cu $0.07 \mathrm{mg}$ \\
\hline & & & & & Surgical 3.5\% & & & & & & Se $82 \mu \mathrm{g}$ & Se $6.3 \mu \mathrm{g}$ \\
\hline & & & & & & & & & & & Zn 14 mg & Zn 1.0 mg \\
\hline \multirow[t]{3}{*}{3} & 12 & $63 / 165$ & 1.69 & 7 & Total 45\% & $27 / 31 / 28 / 20$ & 3 & 27 & 39 & $100 \%, 13$ days + & Cu 3.0 mg & Cu $0.05 \mathrm{mg}$ \\
\hline & & & & & Surgical $45 \%$ & & & & & 10 days Intestamin* & Se $624 \mu \mathrm{g}$ & Se $9.9 \mu \mathrm{g}$ \\
\hline & & & & & & & & & & & Zn 65 mg & Zn $1.0 \mathrm{mg}$ \\
\hline \multirow[t]{3}{*}{4} & 15 & $60 / 173$ & 1.69 & 6 & Total 40\% & $29 / 24 / 19 / 24$ & 6 & 25 & 36 & $100 \%, 14$ days + & Cu $2.47 \mathrm{mg}$ & Cu $0.04 \mathrm{mg}$ \\
\hline & & & & & Surgical $20 \%$ & & & & & 10 days Intestamin* & Se $553 \mu \mathrm{g}$ & Se $9.2 \mu \mathrm{g}$ \\
\hline & & & & & & & & & & & Zn 60 mg & Zn $1.0 \mathrm{mg}$ \\
\hline
\end{tabular}
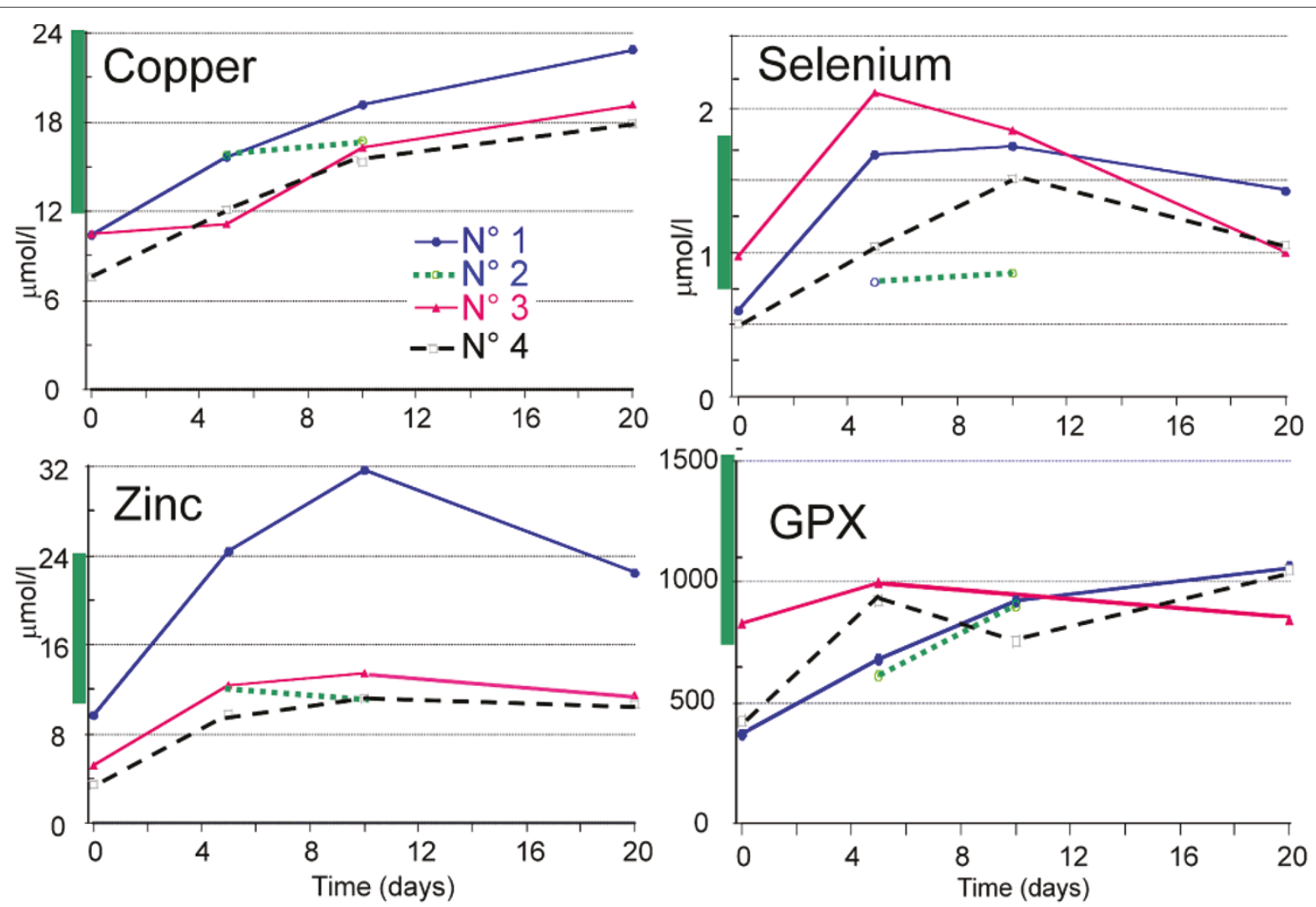

Figure 1. Evolution of copper, zinc, selenium and glutathione peroxidase (GPX) plasma concentrations over time. Low on admission, normalization was achieved by day 5 of the ICU stay. The green bars on the left side of the $y$-axis show the respective reference values. 


\section{Acknowledgments}

To Eddie Roberts and John Dutton (Unit of Clinical Chemistry, Royal Liverpool Hospital, Liverpool, UK) for analytical support.

\section{Author details}

'Paediatric Intensive Care Service, University Hospital Center (CHUV), Lausanne, Switzerland. ${ }^{2}$ Department of Clinical Chemistry, Royal Liverpool University Hospital and University of Liverpool, Liverpool, L69 3BX, United Kingdom. ${ }^{3}$ Adult Intensive Care Medicine Service and Burn Center, CHUV BH-08.612, Rue du Bugnon 46, CH-1011 Lausanne, Switzerland.

Published: 27 August 2010

\section{References}

1. Voruganti VS, Klein GL, Lu HX, Thomas S, Freeland-Graves JH, Herndon DN: Impaired zinc and copper status in children with burn injuries: need to reassess nutritional requirements. Burns 2005, 31:711-716.

2. Pochon JP, Klöti J: Zinc and copper replacement therapy in children with deep burns. Burns 1979, 5:123-126.
3. Berger MM, Baines M, Raffoul W, Benathan M, Chiolero RL, Reeves C, Revelly J-P, Cayeux M-C, Sénéchaud I, Shenkin A: Trace element supplementation after major burns modulates antioxidant status and clinical course by way of increased tissue trace element concentration. Am J Clin Nutr 2007 , 85:1293-1300.

4. Berger MM: Acute copper and zinc deficiency due to exudative losses substitution versus nutritional requirements. Burns 2006, 32:393.

5. Barbosa E, Faintuch J, Machado Moreira EA, Gonçalves da Silva VR, Lopes Pereima MJ, Martins Fagundes RL, Filho DW: Supplementation of vitamin E, vitamin $C$, and zinc attenuates oxidative stress in burned children: a randomized, double-blind, placebo-controlled pilot study. J Burn Care Res 2009, 30:859-866.

doi:10.1186/cc9198

Cite this article as: Stucki $P$, et al:. Substitution of exudative trace element losses in burned children. Critical Care 2010, 14:439. 